\title{
REVIEW
}

\section{Tackling Ebola: new insights into prophylactic and therapeutic intervention strategies}

\author{
Emmie de Wit, Heinz Feldmann and Vincent J Munster*
}

\begin{abstract}
Since its discovery in 1976, Ebolavirus has caused periodic outbreaks of viral hemorrhagic fever associated with severe and often fatal disease. Ebolavirus is endemic in Central Africa and the Philippines. Although there is currently no approved treatment available, the past 10 years has seen remarkable progress in our understanding of the pathogenicity of Ebolavirus and the development of prophylactic and post-exposure therapies against it. In vitro and in vivo experiments have shown that Ebolavirus pathogenicity is multifactorial, including viral and host determinants. Besides their function in the virus replication cycle, the viral glycoprotein, nucleoprotein, minor matrix protein and polymerase cofactor are viral determinants of pathogenicity, with evasion of the host innate and adaptive immune responses as the main mechanism. Although no licensed Ebolavirus vaccines are currently available, vaccine research in non-human primates, the 'gold standard'animal model for Ebolavirus, has produced several promising candidates. A combination of DNA vaccination and a recombinant adenovirus serotype 5 boost resulted in cross-protective immunity in non-human primates. A recombinant vesicular stomatitis vaccine vector protected non-human primates in pre- and post-exposure challenge studies. Several antiviral therapies are currently under investigation, but only a few of these have been tested in non-human primate models. Antisense therapies, in which oligonucleotides inhibit viral replication, have shown promising results in non-human primates following post-exposure treatment. In light of the severity of Ebolavirus disease and the observed increase in Ebolavirus outbreaks over the past decade, the expedited translation of potential candidate therapeutics and vaccines from bench to bedside is currently the most challenging task for the field. Here, we review the current state of Ebolavirus research, with emphasis on prophylactic and therapeutic intervention strategies.
\end{abstract}

\section{Introduction}

The genus Ebolavirus (EBOV) in the Filoviridae family contains five distinct species [1]. Ebolaviruses are known for their ability to cause devastating viral hemorrhagic fever outbreaks in humans and great apes, but the natural reservoir for EBOV has remained elusive for many years. The recent detection of EBOV antibodies and viral RNA in several African fruit bat species indicated their role as a natural reservoir for EBOV [2-5].

EBOV was discovered in humans during two concurrent outbreaks in 1976. One of these occurred in the Democratic Republic of Congo and was caused by Zaire ebolavirus (ZEBOV) [6], whereas the other, unrelated outbreak that occurred in Sudan was caused by Sudan

*Correspondence: vincent.munster@niaid.nih.gov

Laboratory of Virology, Division of Intramural Research, National Institute of Allergy and Infectious Diseases, National Institutes of Health, Hamilton, 903 South 4th Street, MT 59840, USA ebolavirus (SEBOV; Table 1) [7]. ZEBOV caused several more outbreaks between 1994 and 2008 in Gabon, the Democratic Republic of Congo and the Republic of Congo, with a case-fatality rate ranging from $60 \%$ to $90 \%$. SEBOV reemerged in Sudan in 1979 and 2004 and in Uganda in 2000 to 2001 . SEBOV has a case-fatality rate of 40 to $60 \%$ [8].

Reston ebolavirus (REBOV) was discovered in 1989 during a disease outbreak in cynomolgus macaques imported into the US from the Philippines [9]. Outbreaks of REBOV occurred again in 1990, 1992 and 1996 in the US and Italy in cynomolgus macaques imported from the same facility in the Philippines and, in 2008, REBOV emerged in domestic pigs in the Philippines [10]. REBOV has not yet been associated with disease in humans, but there is evidence for REBOV infection in humans in close contact with REBOV-infected macaques and swine [10-12].

Côte d'Ivoire ebolavirus (CIEBOV) was discovered during an epizootic (animal epidemic) in chimpanzees in the Taï National Park in Côte d'Ivoire in 1994, in the first 
Table 1. Chronology of Ebolavirus outbreaks

\begin{tabular}{|c|c|c|c|}
\hline Year & Location & Virus & Species \\
\hline 1976 & Democratic Republic of Congo & ZEBOV & Humans \\
\hline 1976 & Sudan & SEBOV & Humans \\
\hline 1977 & Democratic Republic of Congo & ZEBOV & Humans \\
\hline 1979 & Sudan & SEBOV & Humans \\
\hline 1989-1990 & USA & REBOV & Cynomolgus macaques \\
\hline 1992 & Italy & REBOV & Cynomolgus macaques \\
\hline 1994 & Gabon & ZEBOV & Humans \\
\hline 1994 & Ivory Coast & CIEBOV & Chimpanzees, humans \\
\hline 1995 & Democratic Republic of Congo & ZEBOV & Humans \\
\hline 1996 & Gabon & ZEBOV & Humans \\
\hline 1996 & Gabon & ZEBOV & Humans \\
\hline 1996 & USA & REBOV & Cynomolgus macaques \\
\hline 2000-2001 & Uganda & SEBOV & Humans \\
\hline $2001-2002^{*}$ & Gabon & ZEBOV & Humans, gorillas, duikers \\
\hline $2001-2005^{*}$ & Republic of Congo & ZEBOV & Humans, gorillas, chimpanzees, duikers \\
\hline 2004 & Sudan & SEBOV & Humans \\
\hline $2007-2008^{*}$ & Republic of Congo & ZEBOV & Humans \\
\hline $2007-2008$ & Uganda & BEBOV & Humans \\
\hline 2008 & Philippines & REBOV & Swine \\
\hline
\end{tabular}

*Multiple independent outbreaks. Abbreviations: BEBOV, Bundibugyo ebolavirus; CIEBOV, Côte d'Ivoire ebolavirus; REBOV, Reston ebolavirus; SEBOV, Sudan ebolavirus; ZEBOV, Zaire ebolavirus.

confirmed introduction of an EBOV into a great ape population [13]. So far, CIEBOV has only caused a single, non-fatal human case. In 2007 to 2008 a large outbreak of viral hemorrhagic fever with a case-fatality rate of approximately $25 \%$ occurred in humans in Uganda. The causative agent of this outbreak was identified as a novel species of EBOV, Bundibugyo ebolavirus (BEBOV) [14]. ZEBOV, and to a lesser extent CIEBOV, are responsible for devastating outbreaks in the African great ape populations, with ZEBOV being associated with the decline in great ape populations in the Congo basin [15-17].

Symptoms of Ebolavirus disease usually occur after an incubation period ranging from several days to 3 weeks [8]. Onset of disease symptoms is sudden and consists of fever, headache and muscle and joint pain and progresses to include diarrhea, loss of appetite (anorexia), vomiting, chest pain, shortness of breath, coughing and a maculopapular rash (a skin rash consisting of discoloration and raised spots). At the peak of illness hemorrhagic manifestations develop, although not in all cases; these include blood in the stools (melena) or vomit (hematemesis), small hemorrhages under the skin (petechiae), and bleeding from the nose, gums, from venipuncture sites and from the conjunctiva of the eye. Ultimately, fatal cases progress to coma, shock and death $[7,18]$. Massive production of proinflammatory cytokines, the absence of type I interferon (IFN) production, the absence of antibody induction and loss of peripheral CD4 ${ }^{+}$and $\mathrm{CD}^{+}$ $\mathrm{T}$ lymphocytes are correlated with fatal outcome in EBOV infections [19-21].

EBOV forms a filamentous particle of uniform diameter but variable length and shape (Figure 1). The viral envelope is derived from the host cell membrane on which the EBOV envelope glycoprotein (GP), which mediates entry into the host cell, is expressed. The EBOV negative-strand RNA genome contains seven genes and is encapsidated by the nucleoprotein (NP). The encapsidated genome, the minor nucleoprotein (VP30), the viral polymerase (L) and the polymerase cofactor (VP35) are required for replication and transcription of the viral RNA. The matrix protein (VP40) is required for budding of the virus particle from the plasma membrane; the minor matrix protein (VP24) facilitates virus budding [8]. GP is produced only after translational editing; the primary gene product of the gene that encodes GP is soluble GP (sGP) [8], a nonstructural protein of poorly understood function, which was shown to reverse the permeability-increasing effect of TNF $\alpha$ on endothelial cells and partially restore the endothelial barrier function of these cells [22].

Here, we provide an overview of our understanding of EBOV pathogenicity and the progress in development of 


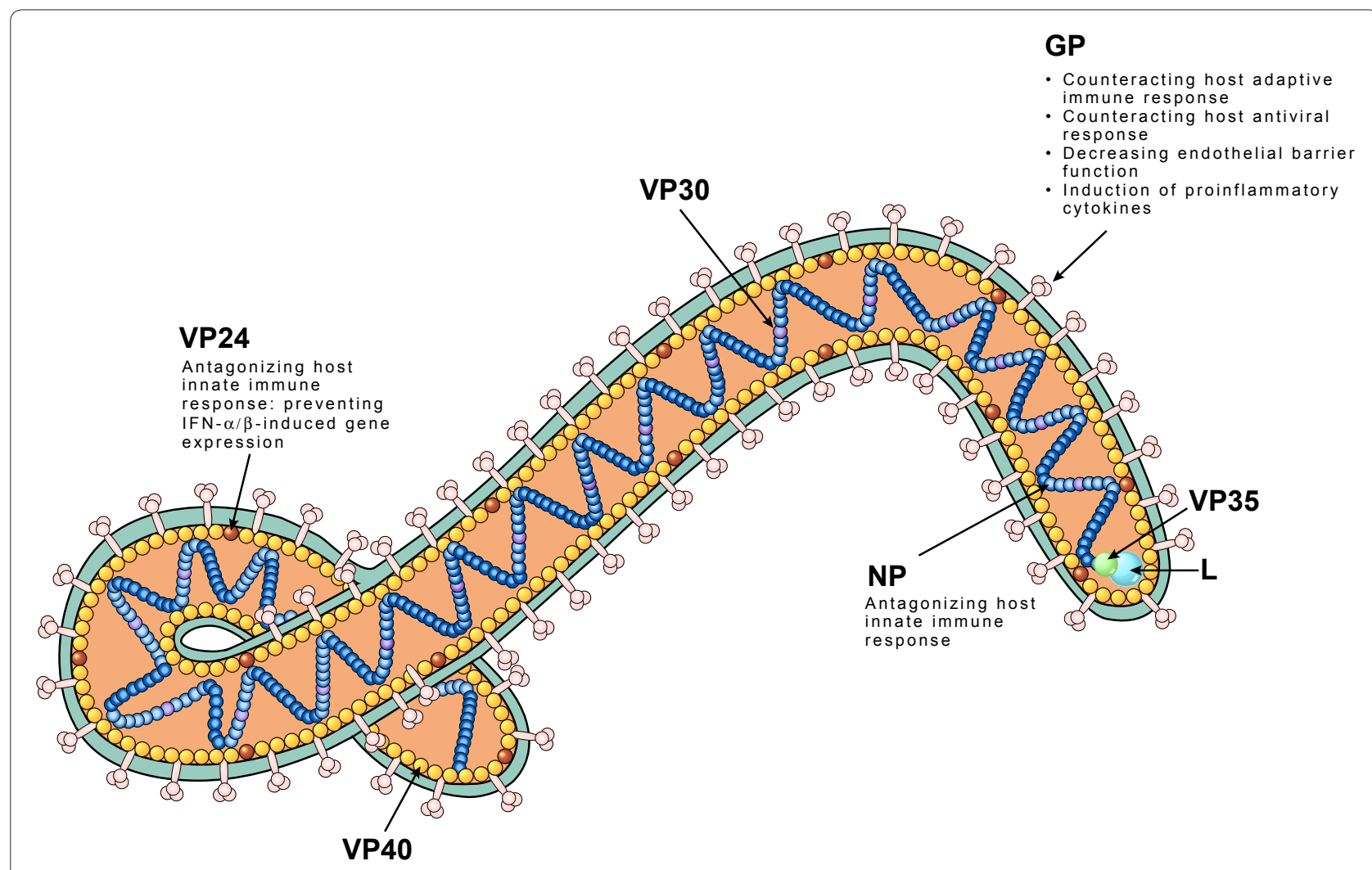

Figure 1. Determinants of Ebolavirus pathogenicity. Schematic representation of an Ebolavirus particle. The roles of GP, NP, VP24 and VP35 in the pathogenesis of EBOV, as discussed in the main text, are indicated.

vaccines and antivirals for the prevention and treatment of EBOV infection. We also discuss the potential role of genomics in EBOV research.

\section{Determinants of pathogenicity}

Apart from direct tissue damage resulting from EBOV replication, the severity of EBOV disease also results from indirect effects of virus replication, such as the induction of proinflammatory cytokines, depletion of $\mathrm{T}$ lymphocytes and coagulation abnormalities. In experimental infection of cynomolgus macaques, it was shown that the disseminated intravascular coagulation observed in patients is most likely not a direct result of replication of EBOV in endothelial cells [23]. Instead, in vitro experiments showed that GP causes endothelial cell activation, as indicated by upregulation of cell adhesion molecules, and a decrease in endothelial barrier function, potentially leading to edema and shock [22]. The mucin domain of GP, a highly glycosylated region, has a dual effect in counteracting host adaptive immunity: not only does the mucin domain shield epitopes on GP that could otherwise be recognized by antibodies, it also shields major histocompatibility complex I molecules, thereby impairing antigen presentation by the host cell $[24,25]$.
Another effect of GP on the host adaptive immune response is the presence of a 17-mer peptide that causes apoptosis of $\mathrm{CD} 4^{+}$and $\mathrm{CD} 8^{+}$cells in vitro [26]. Besides adaptive immunity, GP also affects the innate immune system by inducing proinflammatory cytokines and suppressor of cytokine signaling 1 (SOCS1) through interacting with Toll-like receptor 4 [27]. GP counters the host antiviral activity of tetherin (also known as Bst-2 or CD317), which retains virus particles at the cell surface after budding, through a direct interaction of GP with tetherin [28] (Figure 1).

VP24 and NP were shown to be important determinants of pathogenicity in vivo; mutations in these proteins were responsible for adaptation of ZEBOV to mice [29] and guinea pigs [30] through their ability to counteract the IFN-induced innate immune response [29] (Figure 1). Although it is not clear how NP counteracts the innate immune response, it has been shown in experiments in vitro that VP24 prevents IFN- $\alpha / \beta-$ induced gene expression and counteracts the antiviral effects of IFN- $\beta$ by interacting with karyopherin- $\alpha 1$ (also known as importin- $\alpha$ ) [31]. Karyopherin- $\alpha 1$ mediates nuclear import and, by interacting with this protein, VP24 prevents nuclear accumulation of phosphorylated 
signal transducer and activator of transcription 1 (STAT1) [31], thereby preventing IFN-induced cell signaling. Two regions of VP24 are involved in the interaction with karyopherin- $\alpha 1$ and counteracting the innate immune response: residues 42 and 142-146 [32].

VP35 functions as an important determinant of pathogenicity through blocking IFN- $\alpha / \beta$ production [33] (Figure 1). In vitro, VP35 prevents the activation of interferon regulatory factor 3 (IRF-3) by blocking the virusinduced phosphorylation of this protein [34]. IRF-3 phosphorylation is blocked by VP35 through several mechanisms. First, VP35 binds to double-stranded (ds) RNA, through residues 309 and 312 [35,36], thereby preventing dsRNA-mediated activation of retinoic acidinducible gene 1 (RIG1), which would normally result in phosphorylation and nuclear translocation of IRF-3 and subsequently expression of the IFN- $\alpha / \beta$ genes [35]. Second, VP35 is phosphorylated by $\kappa \mathrm{B}$ kinase epsilon (IKK- $\varepsilon$ ) and TANK-binding kinase 1 (TBK-1), thereby impairing the interaction of these kinases with their substrates IRF-3 and IRF-7 and preventing their phosphorylation [37]. Finally, through an interaction with the protein inhibitor of activated STAT1 (PIAS1) and the ubiquitin-conjugating enzyme Ubc9, VP35 is involved in the SUMOylation of IRF-3 and IRF-7, resulting in decreased transcription of the IFN- $\beta$ gene [38].

The ability of VP35 to bind dsRNA also prevents the phosphorylation of dsRNA-regulated protein kinase $R$ (PKR), which would otherwise result in the phosphorylation of translation initiation factor eIF- $2 \alpha$ and thus block protein synthesis $[39,40]$. Whether the block of PKR phosphorylation is achieved through dsRNA binding of the amino- or carboxy-terminal domain of VP35 is not clear $[39,40]$. Yet another in vitro effect of the ability of the carboxyl terminus of VP35 to bind dsRNA is the suppression of RNA silencing [41]. The importance of dsRNA binding of VP35 in vivo was shown in guinea pigs; in these animals, a virus with mutations at residues 319 and 322 that no longer bound dsRNA was avirulent, whereas the wild-type virus was lethal [42].

Finally, it was shown that the amino terminus of VP35 affects maturation of dendritic cells. In dendritic cells, VP35 suppresses upregulation of co-stimulatory molecules and pro-inflammatory cytokines and attenuates their ability to activate CD4+ $\mathrm{T}$ cells [43].

Several host genes and proteins that might be involved in the pathogenicity of EBOV have been described. A microarray analysis of human hepatoblastoma cells showed that, following infection with EBOV, acute-phase genes, complement genes and genes involved in regulation of coagulation are downregulated [44]. Analysis of gene expression in sequential peripheral blood mononuclear cell samples from EBOV-inoculated non-human primates (NHPs) showed only very few changes in gene expression in the first days after infection; among the earliest observed changes was an increase in expression of IFN-regulated genes from day 2 and 3 after infection onwards. From day 4 after infection onwards, a dramatic change in the gene expression profile was observed, including upregulation of proinflammatory cytokines, chemokines, TNF $\alpha$ - and NFKB-regulated genes, apoptosisregulating genes and fibrin-dissolution genes [45]. More specific host proteins involved in EBOV replication have also been identified. For instance, it was shown in vitro that RhoB and RhoC, members of the small GTP-binding RhoGTPase family, enhanced entry of EBOV into cells [46]. Inhibition of heat-shock protein 90 (Hsp90) in vitro resulted in inhibition of EBOV replication [47]. Furthermore, it was shown that a large number of host cell proteins are incorporated in EBOV particles. Knocking down expression of several of these proteins using small interfering (si)RNA resulted in reduced viral replication, indicating the relevance of the incorporation of these proteins into virus particles [48]. Understanding the molecular mechanisms behind the pathogenicity of EBOV and identification of host factors required for efficient EBOV replication can aid in the development of therapeutic and prophylactic treatments for EBOV.

\section{EBOV vaccine development}

Vaccination is considered one of the primary control strategies for infectious diseases in the human population; however, no licensed EBOV vaccines are currently available. The first attempts to generate EBOV vaccines consisted of classical formulations of inactivated virus with different adjuvants, such as Ribi adjuvants or lipid A-containing liposomes [49-51]. Although some studies resulted in protective immunity in rodent models, most of these strategies were not successful in protecting NHPs from lethal challenge with EBOV. The relative ease with which protection is generated in mouse and guinea pig models seems to have limited predictive value for vaccine efficacy in NHPs, the 'gold standard' animal model for EBOV [52]. However, these rodent models are still valuable for pre-screening vaccine candidates before they advance into NHP models.

The lack of success with classical vaccine approaches naturally led to the search for effective vaccine formulations based on the latest developments in the field, such as viral-vector-based vaccines, DNA vaccines and viruslike particles (VLPs) in a variety of prime-boost strategies. The advantage of using these novel vaccine approaches over the classical vaccine approach is the more robust induction of both innate and adaptive immune responses, humoral as well as cellular, resulting in a better vaccine efficacy. Recent studies into the correlates of protection against EBOV infection suggest that a humoral immune response alone is not sufficient 
Table 2. Promising vaccine and antiviral drug development for the prevention and treatment of Ebolavirus

\begin{tabular}{|c|c|c|c|c|c|}
\hline Treatment & Efficacy & Prophylactic & Therapeutic & Status & References \\
\hline \multicolumn{6}{|l|}{ Vaccines } \\
\hline DNA vaccines & Rodents and NHPs & Yes & Unknown & Phase I clinical trails & {$[57,60]$} \\
\hline Adenovirus & Rodents and NHPs & Yes & Unknown & Phase I clinical trails & {$[62,63]$} \\
\hline rVSV-EBOV & Rodents and NHPs & Yes & Yes & Experimental & [65-68] \\
\hline HPIV3-EBOV & Rodents and NHPs & Yes & Unknown & Experimental & [70] \\
\hline EBOV-VLPS & Rodents and NHPs & Yes & Unknown & Experimental & [71] \\
\hline Replication-deficient ZEBOV & Rodents & Yes & Unknown & Experimental & [72] \\
\hline \multicolumn{6}{|l|}{ Antivirals } \\
\hline rhAPC & Partial in NHPs & Unknown & Yes & Licensed* & {$[75]$} \\
\hline rNAPc2 & Partial in NHPs & Yes & Yes & Phase II clinical trials ${ }^{\dagger}$ & [76] \\
\hline FGI-103, FGI-104 and FGI-106 & Rodents & Yes & Yes $^{\ddagger}$ & Experimental & [81-83] \\
\hline Antisense oligonucleotides & Rodents and NHPs & Yes & Yes & Experimental & [85-88] \\
\hline
\end{tabular}

*Licensed for the treatment of sepsis-induced coagulation disorders. ${ }^{\text {T}}$ The antithrombotic potential of rNAPc2 in orthopedic surgery and coronary revascularization was tested. ${ }^{\ddagger}$ Only FGI-106 was tested therapeutically. Abbreviations: HPIV3, human parainfluenza virus type 3; NHP, non-human primate; rhAPC, recombinant human activated protein C; rNAPc2, nematode anticoagulant protein c2; rVSV, recombinant vesicular stomatitis virus; VLP, virus-like particle.

for protection against EBOV infection, but should be combined with a sufficient activation of the $\mathrm{CD}^{+}$and $\mathrm{CD}^{+} \mathrm{T}$ lymphocytes in order to confer protection [53-57]. The most promising vaccine approaches against EBOV infections are discussed below and in Table 2.

\section{DNA vaccines}

DNA vaccines are purified plasmid preparations containing one or more DNA sequences of the pathogen of interest that are expressed in the recipient on delivery. A DNA vaccine expressing ZEBOV GP elicited a protective immune response in mice [58] and partially protected guinea pigs [59]. A prime-boost vaccine strategy of four inoculations with DNA vectors encoding ZEBOV GP and SEBOV GP and a boost with a recombinant adenovirus 5 vector expressing ZEBOV GP generated cross-protective immunity in NHPs against a heterologous challenge with BEBOV [57]. There are currently no licensed DNA vaccines for use in humans; however, a three-plasmid DNA vaccine encoding ZEBOV GP, SEBOV GP and NP elicited a cellular and humoral immune response in humans after three injections of vaccine in a phase I clinical trial [60]. Several veterinary DNA vaccines against various viruses are currently licensed, including a DNA vaccine for West Nile virus in horses [61].

\section{Recombinant viral vector vaccines}

Recombinant viral vaccine vectors can consist of vectors capable of replication or of replication-deficient vectors. The adenoviral vector is a replication-deficient vaccine vector with a broad cellular tropism used in a wide variety of gene therapy studies. As mentioned above, a combination of a DNA vaccine prime and adenovirus vector boost was able to protect NHPs from lethal
BEBOV challenge [57]. In addition, the incorporation of ZEBOV and SEBOV GP in a single adenovirus vector provided complete protection in NHPs against ZEBOV and SEBOV challenge, demonstrating the potential of generating immunity against different EBOV species in NHPs [62]. A recently completed phase I clinical trial showed that recombinant adenovirus serotype 5 expressing ZEBOV and SEBOV GP was safe for use in humans [63].

The use of replication-competent vector-based vaccines has been very successful in the development of veterinary vaccines; ten recombinant poultry vaccines are currently licensed [64]. For EBOV, replication competent recombinant vesicular stomatitis virus (rVSV) vectors expressing EBOV genes have been generated successfully. A single administration of rVSV expressing ZEBOV GP elicited complete protection of NHPs from homologous challenge, but not from heterologous SEBOV challenge [65]. A multivalent vaccine composed of equal parts of rVSV expressing GPs of Marburgvirus (MARV), ZEBOV and SEBOV offered protection against challenge with MARV, ZEBOV, SEBOV and CIEBOV in NHPs [66]. Another important potential of the rVSV-based EBOV vaccines is their use as post-exposure treatment. When rVSV with ZEBOV GP or SEBOV GP was administered to NHPs 30 minutes after homologous EBOV challenge, the rVSV vaccine was able to protect $50 \%$ of ZEBOV-infected animals and $100 \%$ of SEBOV-infected animals $[67,68]$. The rVSV ZEBOV GP was recently used to contain a potential laboratory exposure with ZEBOV and was administered 40 hours after the incident [69].

Another replication-competent viral vector, human parainfluenza virus type 3 (HPIV3) expressing ZEBOV GP, was highly immunogenic after two intranasal 
administrations and protected NHPs from homologous challenge [70].

\section{Virus-like particle vaccines}

VLPs are particles generated by the expression of one or more viral proteins and mimic the natural viral conformation but do not contain viral genetic material. EBOV VLPs were generated by simultaneously expressing GP, NP and VP40 of ZEBOV in 293T cells, combined with Ribi adjuvant and administered three times to NHPs, resulting in protection against homologous ZEBOV challenge [71]. Another vaccine candidate recently investigated was a replication-deficient ZEBOV lacking the VP30 gene. Two vaccinations with this virus protected mice and guinea pigs from lethal ZEBOV challenge [72].

Although there are now promising vaccine candidates, the correlates of protection from EBOV infection are still poorly understood. Combining existing vaccine candidates with research into the correlates of protection and applying genomics strategies should result in improved vaccines effective as post-exposure treatment and/or vaccines that cross-protect against all four African EBOV.

\section{Development of EBOV antiviral therapeutics}

There has been an active search for effective therapeutic treatments for EBOV infection; unfortunately, these have so far had limited success (Table 2). Licensed therapeutics for the treatment of other viral infections, such as IFN- $\alpha 2 b$ and ribavirin (used for the treatment of, for example, hepatitis $\mathrm{B}$ and $\mathrm{C}$ virus) did not show prophylactic or therapeutic value for the treatment of EBOV $[73,74]$. Limited therapeutic efficacy was seen with recombinant human activated protein $\mathrm{C}$ (rhAPC), a drug licensed for the treatment of sepsis-induced coagulation disturbances: two out of eleven NHPs survived a lethal ZEBOV challenge and there was a significant increase in time to death [75]. More promising results were obtained using nematode anticoagulant protein c2 (rNAPc2), a drug under evaluation for treatment of coagulation abnormalities through inhibition of the fVIIa tissue factor complex. rNAPc2 was able to protect three out of nine NHPs after a lethal ZEBOV challenge using both prophylactic (10 minutes before challenge) and postexposure (24 hours after challenge) treatment regimes [76]. Pre-exposure treatment of NHPs with a neutralizing monoclonal antibody failed to protect them when challenged with a lethal dose of ZEBOV [77].

The discovery of effective EBOV antiviral compounds has been hampered by the need for biosafety level 4 (BSL4) facilities to work safely with EBOV and the lack of high-throughput screening technologies. The development of alternative screening strategies, such as the use of VLPs and pseudotyped VSV, as well as of minigenome systems, has enabled the screening of compound libraries in a high-throughput manner at lower containment level (BSL2). In addition, the increased number of BSL4 laboratories combined with the development of reverse genetics technologies for EBOV [78], leading to the creation of EBOV expressing green fluorescent protein (EBOV-GFP) [79,80], has enabled high-throughput screening of anti-EBOV compounds within high containment laboratories.

\section{High-throughput antiviral drug screening}

The screening of compound libraries using EBOV-GFP has identified several compounds showing in vitro and in vivo antiviral activity. The antiviral compounds FGI-103, FGI-104 and FGI-106 showed in vivo efficacy against ZEBOV in a mouse model following treatment before and throughout the remainder of the study with these compounds [81-83]. FGI-106 also conferred complete protection to mice challenged with ZEBOV when administered from the time of challenge onwards, and $90 \%$ protection with post-exposure treatment [81]. EBOV enters the host cell by fusion of the viral envelope and the host cell membrane. Given that several other enveloped viruses use a similar process, this allows the development of compounds with broad-spectrum antiviral activity. One such molecule, LJ001, was discovered using a pseudotyped VSV virus with a luciferase reporter [84]. LJ001 binds to the virus envelope and inhibits virus-cell fusion for a large range of enveloped viruses, including EBOV. Pretreatment of mice with LJ001 reduced ZEBOV mortality by $80 \%$, but the compound did not show any efficacy in a post-challenge model, presumably as a result of limited bioavailability [84].

\section{Antisense therapy}

Currently, the most promising studies in antiviral treatment of EBOV use the ability of virus-gene-specific oligonucleotides to interfere with translation of viral mRNA. This antisense strategy inhibits EBOV replication, resulting in a reduction in the pathogenic effects of EBOV and allowing the immune system more time to clear the infection. A combination antisense strategy targeted at ZEBOV L, VP24 and VP35 was an efficacious post-exposure treatment in several rodent and NHP studies [85-88]. Depending on the time of intravenous treatment, $66 \%$ or $100 \%$ of NHPs were protected from lethal challenge [86]. A similar study, using chemically modified oligonucleotides called phosphorodiamidate morpholino oligomers, conferred $60 \%$ protection against lethal ZEBOV challenge in NHPs following intraperitoneal, subcutaneous and intravenous administration. Although the 30- to 60-minute interval between ZEBOV challenge and the start of the therapeutic treatment used in both studies indicates the potential of antisense 
therapy in the treatment of accidental exposures, the feasibility for effective use in an outbreak setting remains to be determined.

\section{Future perspectives}

In the past decade, there has been significant progress in the general understanding of EBOV replication and pathogenesis. The increased availability of BSL4 facilities and the development of molecular tools to study parts of the basic biology of EBOV under BSL2 conditions will undoubtedly lead to a more comprehensive understanding of EBOV in the near future. The increasing capability and capacity of tools such as mRNA expression profiling, high-throughput and 454 sequencing and RNA interference technologies have greatly contributed to our knowledge in biomedical research, including virology. These new technologies have been rapidly implemented in fundamental and clinical research settings. The broad range of applications in virology of these new genomic technologies encompasses areas such as epidemiology, viral pathogenesis, host response and the development of diagnostics, vaccines, and antivirals. However, in comparison with other viral pathogens, such as influenza A virus and HIV, research of EBOV has only marginally benefitted from these developments. A more extensive use of genomic and post-genomic approaches in EBOV research will probably result in a rapid advance in our understanding of EBOV pathogenesis and virus-host interactions, such as receptor usage, viral replication or interactions with innate and adaptive immune responses. The identification of interactions of EBOV with host cell factors, such as Hsp90, and other potential targets for therapeutic intervention [46-48] may result in targeted design of antiviral therapeutics [89]. Likewise, the availability of EBOV genomic sequences and understanding of the virus replication cycle may allow novel vaccine approaches, such as 'reverse vaccinology' [90]. Future EBOV research should therefore focus on understanding the cellular processes involved in EBOV replication and pathogenesis, using broad genomics and proteomics approaches, combining data obtained in experimental settings in vitro and in vivo.

Whereas the screening of compound libraries has yielded promising candidates with potent antiviral characteristics, the solving of crystal structures of EBOV proteins and their associated biological function will hopefully result in the rational design of antiviral drugs, similar to antivirals used for the treatment of HIV and influenza A virus [91-94]. Moreover, in the absence of vaccines or antivirals directed at EBOV, research should be aimed at interfering with the indirect effects of EBOV replication, such as modulating the innate immune response and preventing lymphocyte depletion and coagulation abnormalities.
Here, we have highlighted several promising candidates for vaccine and antiviral use (Table 2). In the light of the severity of EBOV disease and the observed increase in outbreaks over the past decade, the expedited translation of these potential candidate therapeutics from bench to bedside is of the utmost importance. The severity of EBOV disease and the sporadic nature of outbreaks render normal phase III efficacy trials neither ethical nor feasible. However, the availability of the so-called 'animal rule' allows the licensing of vaccines or antivirals on the basis of evidence in well-characterized animal models, in addition to the phase I and phase II requirements [95-97]. Therefore, it is crucial to validate the existing NHP models with respect to their feasibility to function as models for human EBOV infection. In addition, it is crucial to obtain more in-depth knowledge on the correlates of protection against EBOV infection, both for vaccines and antivirals, using genomics and proteomics approaches, which will allow a more targeted vaccine and antiviral design approach.

Lastly, clear identification of the target populations for the various therapeutic intervention strategies is necessary. Whereas most of the discussed post-exposure vaccine and antiviral therapeutic strategies will be particularly useful in laboratory incidents and outbreak situations, prophylactic vaccine strategies targeting the rural populations in EBOV endemic regions in general are questionable. Specific targeting of certain risk groups or ring vaccination (vaccination of all individuals in a prescribed area around an outbreak) approaches during outbreaks seem more feasible but would still require a combined international effort to ensure the deployment of available vaccines where most needed. Moreover, although the focus of the therapeutic intervention strategies has been largely on preventing EBOV disease in humans, similar approaches are urgently needed to prevent the introduction and spread of EBOV into the endangered gorilla and chimpanzee populations of Central Africa, which could be pushed to the brink of extinction by EBOV outbreaks.

\section{Abbreviations}

BEBOV, Bundibugyo ebolavirus; BSL, biosafety level; CIEBOV, Côte d'Ivoire ebolavirus; dsRNA double-stranded RNA; EBOV, Ebolavirus; GP, glycoprotein; HPIV3, human parainfluenza virus type 3; IFN, interferon; L, RNA-dependent RNA polymerase; NHP, non-human primate; NP, nucleoprotein; REBOV, Reston ebolavirus; rhAPC, recombinant human activated protein $C_{;}$rNAPC2, nematode anticoagulant protein c2; rVSV, recombinant vesicular stomatitis virus; SEBOV, Sudan ebolavirus; VLP, virus-like particle; VP24, minor matrix protein; VP30, minor nucleoprotein; VP35, polymerase cofactor; VP40, matrix protein; ZEBOV, Zaire ebolavirus.

\section{Competing interests}

HF claims intellectual property for VSV-based filovirus vaccines. EdW and VJM declare that they have no competing interests.

\section{Authors' contributions}

All authors contributed equally to the concept, literature search, writing and figure design for this manuscript. 


\section{Acknowledgements}

The authors thank Anita Mora for help with figure design. This work was supported by the Division of Intramural Research, National Institute of Allergy and Infectious Diseases, National Institutes of Health.

Published: 27 January 2011

\section{References}

1. Feldmann H, Geisbert TW, Jahrling PB, Klenk HD, Netesov SV, Peters CJ, Sanchez A, Swanepoel R, Volchkov VE: Filoviridae. In Virus Taxonomy: VIIIth Report of the International Committee on Taxonomy of Viruses. Edited by Fauquet C, Mayo MA, Maniloff J, Desselberger U, Ball LA. London: Elsevier/ Academic Press; 2005:645-653.

2. Hayman DT, Emmerich P, Yu M, Wang LF, Suu-Ire R, Fooks AR, Cunningham AA, Wood JL: Long-term survival of an urban fruit bat seropositive for Ebola and Lagos bat viruses. Plos ONE 2010, 5:e11978.

3. Leroy EM, Kumulungui B, Pourrut X, Rouquet $P$, Hassanin A, Yaba P, Delicat A, Paweska JT, Gonzalez JP, Swanepoel R: Fruit bats as reservoirs of Ebola virus. Nature 2005, 438:575-576.

4. Pourrut X, Delicat A, Rollin PE, KsiazekTG, Gonzalez JP, Leroy EM: Spatial and temporal patterns of Zaire ebolavirus antibody prevalence in the possible reservoir bat species. J Infect Dis 2007, 196 Suppl 2:S176-S183.

5. Pourrut X, Souris M, Towner JS, Rollin PE, Nichol ST, Gonzalez JP, Leroy E: Large serological survey showing cocirculation of Ebola and Marburg viruses in Gabonese bat populations, and a high seroprevalence of both viruses in Rousettus aegyptiacus. BMC Infect Dis 2009, 9:159.

6. Ebola haemorrhagic fever in Zaire, 1976. Bull World Health Organ 1978 56:271-293

7. Ebola haemorrhagic fever in Sudan, 1976. Report of a WHO/International Study Team. Bull World Health Organ 1978, 56:247-270.

8. Sanchez A, Geisbert TW, Feldmann H: Filoviridae: Marburg and Ebola Viruses. In Fields Virology. 5th edition. Edited by Knipe DM, Howley PM. Philadelphia: Lippincott Williams \& Wilkins; 2007:1409-1448.

9. Jahrling PB, Geisbert TW, Dalgard DW, Johnson ED, Ksiazek TG, Hall WC, Peters $\mathrm{CJ}$ : Preliminary report: isolation of Ebola virus from monkeys imported to USA. Lancet 1990, 335:502-505

10. Barrette RW, Metwally SA, Rowland JM, Xu L, Zaki SR, Nichol ST, Rollin PE, Towner JS, Shieh WJ, Batten B, Sealy TK, Carrillo C, Moran KE, Bracht AJ, Mayr GA, Sirios-Cruz M, Catbagan DP, Lautner EA, Ksiazek TG, White WR, McIntosh MT: Discovery of swine as a host for the Reston ebolavirus. Science 2009 325:204-206.

11. Update: filovirus infections among persons with occupational exposure to nonhuman primates. MMWR Morb Mortal Wkly Rep 1990, 39:266-267; 273

12. Miranda ME, White ME, Dayrit MM, Hayes CG, Ksiazek TG, Burans JP. Seroepidemiological study of filovirus related to Ebola in the Philippines. Lancet 1991, 337:425-426.

13. Le Guenno B, Formenty P, Wyers M, Gounon P, Walker F, Boesch C: Isolation and partial characterisation of a new strain of Ebola virus. Lancet 1995, 345:1271-1274.

14. Towner JS, Sealy TK, Khristova ML, Albarino CG, Conlan S, Reeder SA, Quan PL, Lipkin WI, Downing R, Tappero JW, Okware S, Lutwama J, Bakamutumaho B, Kayiwa J, Comer JA, Rollin PE, KsiazekTG, Nichol ST: Newly discovered ebola virus associated with hemorrhagic fever outbreak in Uganda. PLOS Pathog 2008, 4:e1000212

15. Formenty P, Boesch C, Wyers M, Steiner C, Donati F, Dind F, Walker F, Le Guenno B: Ebola virus outbreak among wild chimpanzees living in a rain forest of Cote d'Ivoire. J Infect Dis 1999, 179 Suppl 1:S120-S126.

16. Leroy EM, Rouquet P, Formenty P, Souquiere S, Kilbourne A, Froment JM, Bermejo M, Smit S, Karesh W, Swanepoel R, Zaki SR, Rollin PE: Multiple Ebola virus transmission events and rapid decline of central African wildlife. Science 2004, 303:387-390.

17. Rouquet P, Froment JM, Bermejo M, Kilbourn A, Karesh W, Reed P, Kumulungui B, Yaba P, Delicat A, Rollin PE, Leroy EM: Wild animal mortality monitoring and human Ebola outbreaks, Gabon and Republic of Congo, 2001-2003. Emerg Infect Dis 2005, 11:283-290.

18. Bwaka MA, Bonnet MJ, Calain P, Colebunders R, De Roo A, Guimard Y, Katwik KR, Kibadi K, Kipasa MA, Kuvula KJ, Mapanda BB, Massamba M, Mupapa KD, Muyembe-Tamfum JJ, Ndaberey E, Peters CJ, Rollin PE, Van den Enden E: Ebola hemorrhagic fever in Kikwit, Democratic Republic of the Congo: clinical observations in 103 patients. J Infect Dis 1999, 179 Suppl 1:S1-S7

19. Baize S, Leroy EM, Georges-Courbot MC, Capron M, Lansoud-Soukate J, Debre
P, Fisher-Hoch SP, McCormick JB, Georges AJ: Defective humoral responses and extensive intravascular apoptosis are associated with fatal outcome in Ebola virus-infected patients. Nat Med 1999, 5:423-426.

20. Villinger F, Rollin PE, Brar SS, Chikkala NF, Winter J, Sundstrom JB, Zaki SR, Swanepoel R, Ansari AA, Peters CJ: Markedly elevated levels of interferon (IFN)-gamma, IFN-alpha, interleukin (IL)-2, IL-10, and tumor necrosis factor-alpha associated with fatal Ebola virus infection. J Infect Dis 1999, 179 Suppl 1:S188-S191

21. Wauquier N, Becquart P, Padilla C, Baize S, Leroy EM: Human fatal zaire ebola virus infection is associated with an aberrant innate immunity and with massive lymphocyte apoptosis. PLoS Negl Trop Dis 2010, 4:e837.

22. Wahl-Jensen VM, Afanasieva TA, Seebach J, Stroher U, Feldmann H, Schnittler $\mathrm{HJ}$ : Effects of Ebola virus glycoproteins on endothelial cell activation and barrier function. J Virol 2005, 79:10442-10450.

23. Geisbert TW, Young HA, Jahrling PB, Davis KJ, Kagan E, Hensley LE: Mechanisms underlying coagulation abnormalities in ebola hemorrhagic fever: overexpression of tissue factor in primate monocytes/macrophages is a key event. $J$ Infect Dis 2003, 188:1618-1629.

24. Francica JR, Varela-Rohena A, Medvec A, Plesa G, Riley JL, Bates P: Steric shielding of surface epitopes and impaired immune recognition induced by the ebola virus glycoprotein. PLOS Pathog 2010, 6:e1001098.

25. Reynard O, Borowiak M, Volchkova VA, Delpeut S, Mateo M, Volchkov VE: Ebolavirus glycoprotein GP masks both its own epitopes and the presence of cellular surface proteins. J Viro/ 2009, 83:9596-9601.

26. Yaddanapudi K, Palacios G, Towner JS, Chen I, Sariol CA, Nichol ST, Lipkin WI: Implication of a retrovirus-like glycoprotein peptide in the immunopathogenesis of Ebola and Marburg viruses. FASEB J 2006, 20:2519-2530.

27. Okumura A, Pitha PM, Yoshimura A, Harty RN: Interaction between Ebola virus glycoprotein and host toll-like receptor 4 leads to induction of proinflammatory cytokines and SOCS1. J Virol 2010, 84:27-33.

28. Kaletsky RL, Francica JR, Agrawal-Gamse C, Bates P: Tetherin-mediated restriction of filovirus budding is antagonized by the Ebola glycoprotein. Proc Natl Acad Sci U S A 2009, 106:2886-2891.

29. Ebihara H, Takada A, Kobasa D, Jones S, Neumann G, Theriault S, Bray M, Feldmann $\mathrm{H}$, Kawaoka Y: Molecular determinants of Ebola virus virulence in mice. PLoS Pathog 2006, 2:e73.

30. Volchkov VE, Chepurnov AA, Volchkova VA, Ternovoj VA, Klenk HD: Molecular characterization of guinea pig-adapted variants of Ebola virus. Virology 2000, 277:147-155

31. Reid SP, Leung LW, Hartman AL, Martinez O, Shaw ML, Carbonnelle C, Volchkov VE, Nichol ST, Basler CF: Ebola virus VP24 binds karyopherin alpha1 and blocks STAT1 nuclear accumulation. J Viro/ 2006, 80:5156-5167.

32. Mateo M, Reid SP, Leung LW, Basler CF, Volchkov VE: Ebolavirus VP24 binding to karyopherins is required for inhibition of interferon signaling. J Virol 2010, 84:1169-1175.

33. Basler CF, Wang X, Muhlberger E, Volchkov V, Paragas J, Klenk HD, GarciaSastre A, Palese P: The Ebola virus VP35 protein functions as a type I IFN antagonist. Proc Natl Acad Sci U S A 2000, 97:12289-12294.

34. Basler CF, Mikulasova A, Martinez-Sobrido L, Paragas J, Muhlberger E, Bray M, Klenk HD, Palese P, Garcia-Sastre A: The Ebola virus VP35 protein inhibits activation of interferon regulatory factor 3. J Virol 2003, 77:7945-7956.

35. Cardenas WB, Loo YM, Gale M Jr, Hartman AL, Kimberlin CR, Martinez-Sobrido L, Saphire EO, Basler CF: Ebola virus VP35 protein binds double-stranded RNA and inhibits alpha/beta interferon production induced by RIG-I signaling. J Viro/ 2006, 80:5168-5178.

36. Hartman AL, Towner JS, Nichol ST: A C-terminal basic amino acid motif of Zaire ebolavirus VP35 is essential for type I interferon antagonism and displays high identity with the RNA-binding domain of another interferon antagonist, the NS1 protein of influenza A virus. Virology 2004, 328:177-184

37. Prins KC, Cardenas WB, Basler CF: Ebola virus protein VP35 impairs the function of interferon regulatory factor-activating kinases IKKepsilon and TBK-1. J Virol 2009, 83:3069-3077.

38. Chang TH, Kubota T, Matsuoka M, Jones S, Bradfute SB, Bray M, Ozato K: Ebola Zaire virus blocks type I interferon production by exploiting the host SUMO modification machinery. PLOS Pathog 2009, 5:e1000493.

39. Feng Z, Cerveny M, Yan Z, He B: The VP35 protein of Ebola virus inhibits the antiviral effect mediated by double-stranded RNA-dependent protein kinase PKR. J Virol 2007, 81:182-192.

40. Schumann M, Gantke T, Muhlberger E: Ebola virus VP35 antagonizes PKR activity through its C-terminal interferon inhibitory domain. J Viro/ 2009 83:8993-8997. 
41. Haasnoot J, de Vries W, Geutjes EJ, Prins M, de Haan P, Berkhout B: The Ebola virus VP35 protein is a suppressor of RNA silencing. PLoS Pathog 2007, 3:e86.

42. Prins KC, Delpeut S, Leung DW, Reynard O, Volchkova VA, Reid SP, Ramanan P, Cardenas WB, Amarasinghe GK, Volchkov VE, Basler CF: Mutations abrogating VP35 interaction with double-stranded RNA render ebola virus avirulent in guinea pigs. J Virol 2010, 84:3004-3015.

43. Jin H, Yan Z, Prabhakar BS, Feng Z, Ma Y, Verpooten D, Ganesh B, He B: The VP35 protein of Ebola virus impairs dendritic cell maturation induced by virus and lipopolysaccharide. J Gen Virol 2010, 91:352-361.

44. Kash JC, Muhlberger E, Carter V, Grosch M, Perwitasari O, Proll SC, Thomas MJ, Weber F, Klenk HD, Katze MG: Global suppression of the host antiviral response by Ebola- and Marburgviruses: increased antagonism of the type I interferon response is associated with enhanced virulence. J Virol 2006, 80:3009-3020.

45. Rubins KH, Hensley LE, Wahl-Jensen V, Daddario DiCaprio KM, Young HA, Reed DS, Jahrling PB, Brown PO, Relman DA, Geisbert TW: The temporal program of peripheral blood gene expression in the response of nonhuman primates to Ebola hemorrhagic fever. Genome Biol 2007, 8:R174.

46. Quinn K, Brindley MA, Weller ML, Kaludov N, Kondratowicz A, Hunt CL, Sinn PL, McCray PB Jr, Stein CS, Davidson BL, Flick R, Mandell R, Staplin W, Maury W, Chiorini JA: Rho GTPases modulate entry of Ebola virus and vesicular stomatitis virus pseudotyped vectors. J Virol 2009, 83:10176-10186.

47. Smith DR, McCarthy S, Chrovian A, Olinger G, Stossel A, Geisbert TW, Hensley $\mathrm{LE}$, Connor JH: Inhibition of heat-shock protein 90 reduces Ebola virus replication. Antiviral Res 2010, 87:187-194.

48. Spurgers KB, Alefantis T, Peyser BD, Ruthel GT, Bergeron AA, Costantino JA, Enterlein S, Kota KP, Boltz RC, Aman MJ, Delvecchio VG, Bavari S: Identification of essential filovirion-associated host factors by serial proteomic analysis and RNAi screen. Mol Cell Proteomics 2010, 9:2690-2703.

49. Geisbert TW, Pushko P, Anderson K, Smith J, Davis KJ, Jahrling PB: Evaluation in nonhuman primates of vaccines against Ebola virus. Emerg Infect Dis 2002, 8:503-507

50. Lupton HW, Lambert RD, Bumgardner DL, Moe JB, Eddy GA: Inactivated vaccine for Ebola virus efficacious in guineapig model. Lancet 1980, 2:1294-1295.

51. Rao M, Bray M, Alving CR, Jahrling P, Matyas GR: Induction of immune responses in mice and monkeys to Ebola virus after immunization with liposome-encapsulated irradiated Ebola virus: protection in mice requires CD4(+) T cells. J Virol 2002, 76:9176-9185.

52. Bente D, Gren J, Strong JE, Feldmann H: Disease modeling for Ebola and Marburg viruses. Dis Model Mech 2009, 2:12-17.

53. Gupta M, Greer P, Mahanty S, Shieh WJ, Zaki SR, Ahmed R, Rollin PE: CD8mediated protection against Ebola virus infection is perforin dependent. J Immuno/ 2005, 174:4198-4202.

54. Gupta M, Mahanty S, Greer P, Towner JS, Shieh WJ, Zaki SR, Ahmed R, Rollin $P E:$ Persistent infection with ebola virus under conditions of partial immunity. J Virol 2004, 78:958-967.

55. Warfield KL, Olinger G, Deal EM, Swenson DL, Bailey M, Negley DL, Hart MK, Bavari S: Induction of humoral and CD8+T cell responses are required for protection against lethal Ebola virus infection. J Immuno/ 2005, 175:1184-1191.

56. Warfield KL, Perkins JG, Swenson DL, Deal EM, Bosio CM, Aman MJ, Yokoyama WM, Young HA, Bavari S: Role of natural killer cells in innate protection against lethal ebola virus infection. J Exp Med 2004, 200:169-179.

57. Hensley LE, Mulangu S, Asiedu C, Johnson J, Honko AN, Stanley D, Fabozzi G, Nichol ST, Ksiazek TG, Rollin PE, Wahl-Jensen V, Bailey M, Jahrling PB, Roederer $M$, Koup RA, Sullivan NJ: Demonstration of cross-protective vaccine immunity against an emerging pathogenic Ebolavirus species. PLOS Pathog 2010, 6:e1000904

58. Vanderzanden L, Bray M, Fuller D, Roberts T, Custer D, Spik K, Jahrling P, Huggins J, Schmaljohn A, Schmaljohn C: DNA vaccines expressing either the GP or NP genes of Ebola virus protect mice from lethal challenge. Virology 1998, 246:134-144.

59. Xu L, Sanchez A, Yang Z, Zaki SR, Nabel EG, Nichol ST, Nabel GJ: Immunization for Ebola virus infection. Nat Med 1998, 4:37-42.

60. Martin JE, Sullivan NJ, Enama ME, Gordon IJ, Roederer M, Koup RA, Bailer RT, Chakrabarti BK, Bailey MA, Gomez PL, Andrews CA, Moodie Z, Gu L, Stein JA Nabel GJ, Graham BS: A DNA vaccine for Ebola virus is safe and immunogenic in a phase I clinical trial. Clin Vaccine Immunol 2006, 13:1267-1277.
61. APHIS News: USDA issues license for West Nile DNA vaccine for horses [http://www.aphis.usda.gov/lpa/news/2005/07/wnvdna_vs.html]

62. Pratt WD, Wang D, Nichols DK, Luo M, Woraratanadharm J, Dye JM, Holman $\mathrm{DH}$, Dong JY: Protection of nonhuman primates against two species of Ebola virus infection with a single complex adenovirus vector. Clin Vaccine Immunol 2010, 17:572-581.

63. Ledgerwood JE, Costner P, Desai N, Holman L, Enama ME, Yamshchikov G, Mulangu S, Hu Z, Andrews CA, Sheets RA, Koup RA, Roederer M, Bailer R, Mascola JR, Pau MG, Sullivan NJ, Goudsmit J, Nabel GJ, Graham BS: A replication defective recombinant $A d 5$ vaccine expressing Ebola virus GP is safe and immunogenic in healthy adults. Vaccine 2010, 29:304-313.

64. Vaccine development using recombinant DNA technology. Animal agriculture's future through biotechnology [http://www.cast-science.org/ websiteUploads/publicationPDFs/CAST\%20Vaccine\%20Development $\% 20$ Issue\%20Paper\%20FINAL\%20REV153.pdf]

65. Jones SM, Feldmann H, Stroher U, Geisbert JB, Fernando L, Grolla A, Klenk HD, Sullivan NJ, Volchkov VE, Fritz EA, Daddario KM, Hensley LE, Jahrling PB, Geisbert TW: Live attenuated recombinant vaccine protects nonhuman primates against Ebola and Marburg viruses. Nat Med 2005, 11:786-790.

66. Geisbert TW, Geisbert JB, Leung A, Daddario-DiCaprio KM, Hensley LE, Grolla A, Feldmann $\mathrm{H}$ : Single-injection vaccine protects nonhuman primates against infection with marburg virus and three species of ebola virus. J Virol 2009, 83:7296-7304

67. Feldmann H, Jones SM, Daddario-DiCaprio KM, Geisbert JB, Stroher U, Grolla A, Bray M, Fritz EA, Fernando L, Feldmann F, Hensley LE, Geisbert TW: Effective post-exposure treatment of Ebola infection. PLOS Pathog 2007, 3:e2.

68. Geisbert TW, Daddario-DiCaprio KM, Williams KJ, Geisbert JB, Leung A, Feldmann F, Hensley LE, Feldmann H, Jones SM: Recombinant vesicular stomatitis virus vector mediates postexposure protection against Sudan Ebola hemorrhagic fever in nonhuman primates. J Virol 2008, 82:5664-5668.

69. Tuffs A: Experimental vaccine may have saved Hamburg scientist from Ebola fever. BMJ 2009, 338:b1223.

70. Bukreyev A, Rollin PE, Tate MK, Yang L, Zaki SR, Shieh WJ, Murphy BR, Collins $\mathrm{PL}$, Sanchez A: Successful topical respiratory tract immunization of primates against Ebola virus. J Virol 2007, 81:6379-6388.

71. Warfield KL, Swenson DL, Olinger GG, Kalina WV, Aman MJ, Bavari S: Ebola virus-like particle-based vaccine protects nonhuman primates against lethal Ebola virus challenge. J Infect Dis 2007, 196 Suppl 2:S430-S437.

72. Halfmann P, Ebihara H, Marzi A, Hatta Y, Watanabe S, Suresh M, Neumann G, Feldmann H, Kawaoka Y: Replication-deficient ebolavirus as a vaccine candidate. J Virol 2009, 83:3810-3815.

73. Huggins JW: Prospects for treatment of viral hemorrhagic fevers with ribavirin, a broad-spectrum antiviral drug. Rev Infect Dis 1989, 11 Suppl 4:S750-S761.

74. Jahrling PB, Geisbert TW, Geisbert JB, Swearengen JR, Bray M, Jaax NK, Huggins JW, LeDuc JW, Peters CJ: Evaluation of immune globulin and recombinant interferon-alpha2b for treatment of experimental Ebola virus infections. J Infect Dis 1999, 179 Suppl 1:S224-S234.

75. Hensley LE, Stevens EL, Yan SB, Geisbert JB, Macias WL, Larsen T, DaddarioDiCaprio KM, Cassell GH, Jahrling PB, Geisbert TW: Recombinant human activated protein $\mathrm{C}$ for the postexposure treatment of Ebola hemorrhagic fever. J Infect Dis 2007, 196 Suppl 2:S390-S399.

76. Geisbert TW, Hensley LE, Jahrling PB, Larsen T, Geisbert JB, Paragas J, Young HA, Fredeking TM, Rote WE, Vlasuk GP: Treatment of Ebola virus infection with a recombinant inhibitor of factor VIla/tissue factor: a study in rhesus monkeys. Lancet 2003, 362:1953-1958.

77. Oswald WB, Geisbert TW, Davis KJ, Geisbert JB, Sullivan NJ, Jahrling PB, Parren PW, Burton DR: Neutralizing antibody fails to impact the course of Ebola virus infection in monkeys. PLOS Pathog 2007, 3:e9.

78. Volchkov VE, Volchkova VA, Muhlberger E, Kolesnikova LV, Weik M, Dolnik O, Klenk HD: Recovery of infectious Ebola virus from complementary DNA: RNA editing of the GP gene and viral cytotoxicity. Science 2001, 291:1965-1969.

79. Towner JS, Paragas J, Dover JE, Gupta M, Goldsmith CS, Huggins JW, Nichol ST: Generation of eGFP expressing recombinant Zaire ebolavirus for analysis of early pathogenesis events and high-throughput antiviral drug screening. Virology 2005, 332:20-27.

80. Ebihara H, Theriault S, Neumann G, Alimonti JB, Geisbert JB, Hensley LE, Groseth A, Jones SM, Geisbert TW, Kawaoka Y, Feldmann H: In vitro and in vivo characterization of recombinant Ebola viruses expressing enhanced green fluorescent protein. J Infect Dis 2007, 196 Suppl 2:S313-S322. 
81. Aman MJ, Kinch MS, Warfield K, Warren T, Yunus A, Enterlein S, Stavale E, Wang P, Chang S, Tang Q, Porter K, Goldblatt M, Bavari S: Development of a broad-spectrum antiviral with activity against Ebola virus. Antiviral Res 2009, 83:245-251.

82. Kinch MS, Yunus AS, Lear C, Mao H, Chen H, Fesseha Z, Luo G, Nelson EA, Li L, Huang Z, Murray M, Ellis WY, Hensley L, Christopher-Hennings J, Olinger GG, Goldblatt M: FGI-104: a broad-spectrum small molecule inhibitor of viral infection. Am J Trans/ Res 2009, 1:87-98.

83. Warren TK, Warfield KL, Wells J, Enterlein S, Smith M, Ruthel G, Yunus AS, Kinch MS, Goldblatt M, Aman MJ, Bavari S: Antiviral activity of a small-molecule inhibitor of filovirus infection. Antimicrob Agents Chemother 2010, 54:2152-2159.

84. Wolf MC, Freiberg AN, Zhang T, Akyol-Ataman Z, Grock A, Hong PW, Li J, Watson NF, Fang AQ, Aguilar HC, Porotto M, Honko AN, Damoiseaux R, Miller JP, Woodson SE, Chantasirivisal S, Fontanes V, Negrete OA, Krogstad P, Dasgupta A, Moscona A, Hensley LE, Whelan SP, Faull KF, Holbrook MR, Jung $M E$, Lee $B$ : A broad-spectrum antiviral targeting entry of enveloped viruses. Proc Natl Acad Sci U S A 2010, 107:3157-3162.

85. Geisbert TW, Hensley LE, Kagan E, Yu EZ, Geisbert JB, Daddario-DiCaprio K, Fritz EA, Jahrling PB, McClintock K, Phelps JR, Lee AC, Judge A, Jeffs LB, MacLachlan I: Postexposure protection of guinea pigs against a lethal ebola virus challenge is conferred by RNA interference. J Infect Dis 2006 193:1650-1657.

86. Geisbert TW, Lee AC, Robbins M, Geisbert JB, Honko AN, Sood V, Johnson JC, de Jong S, Tavakoli I, Judge A, Hensley LE, Maclachlan I: Postexposure protection of non-human primates against a lethal Ebola virus challenge with RNA interference: a proof-of-concept study. Lancet 2010, 375:1896-1905.

87. Warfield KL, Swenson DL, Olinger GG, Nichols DK, Pratt WD, Blouch R, Stein DA, Aman MJ, Iversen PL, Bavari S: Gene-specific countermeasures against Ebola virus based on antisense phosphorodiamidate morpholino oligomers. PLoS Pathog 2006, 2:e1.

88. Warren TK, Warfield KL, Wells J, Swenson DL, Donner KS, Van Tongeren SA, Garza NL, Dong L, Mourich DV, Crumley S, Nichols DK, Iversen PL, Bavari S: Advanced antisense therapies for postexposure protection against lethal filovirus infections. Nat Med 2010, 16:991-994.
89. Kash JC: Applications of high-throughput genomics to antiviral research: evasion of antiviral responses and activation of inflammation during fulminant RNA virus infection. Antiviral Res 2009, 83:10-20.

90. Rappuoli R: Reverse vaccinology, a genome-based approach to vaccine development. Vaccine 2001, 19:2688-2691.

91. Gomis-Roth FX, Dessen A, Timmins J, Bracher A, Kolesnikowa L, Becker S, Klenk HD, Weissenhorn W: The matrix protein VP40 from Ebola virus octamerizes into pore-like structures with specific RNA binding properties. Structure 2003, 11:423-433.

92. Lee JE, Fusco ML, Hessell AJ, Oswald WB, Burton DR, Saphire EO: Structure of the Ebola virus glycoprotein bound to an antibody from a human survivor. Nature 2008, 454:177-182.

93. Lee JE, Kuehne A, Abelson DM, Fusco ML, Hart MK, Saphire EO: Complex of a protective antibody with its Ebola virus GP peptide epitope: unusual features of a V lambda(x) light chain. J Mol Bio/ 2008, 375:202-216.

94. Leung DW, Shabman RS, Farahbakhsh M, Prins KC, Borek DM, Wang TJ, Muhlberger E, Basler CF, Amarasinghe GK: Structural and functional characterization of Reston Ebola virus VP35 interferon inhibitory domain. $\mathrm{J}$ Mol Biol 2010, 399:347-357.

95. MacGill T, Schrager L, Mathis M, Pelsor F, Shapiro A, Cress L, Leissa B, Roberts R: Development of drug medical countermeasures through the "animal rule". Chem-Biol Interact 2006, 161:197.

96. Roberts R, McCune SK: Animal studies in the development of medical countermeasures. Clin Pharmacol Ther 2008, 83:918-920.

97. Sullivan NJ, Martin JE, Graham BS, Nabel GJ: Correlates of protective immunity for Ebola vaccines: implications for regulatory approval by the animal rule. Nat Rev Microbio/ 2009, 7:393-400.

doi:10.1186/gm219

Cite this article as: de Wit E, et al:: Tackling Ebola: new insights into prophylactic and therapeutic intervention strategies. Genome Medicine 2011, 3:5. 